Journal of Clinical Investigation
Vol. 42, No. 3, 1963

\title{
NATURE OF A PLATELET-AGGLUTINATING FACTOR IN SERUM OF PATIENTS WITH IDIOPATHIC THROMBOCYTOPENIC PURPURA *
}

\author{
By DUDLEY P. JACKSON, HANS J. SCHMID, PHILIP D. ZIEVE, $\dagger$ JACK LEVIN, \\ AND C. LOCKARD CONLEY \\ (From the Department of Medicine, The Johns Hopkins University and Hospital, \\ Baltimore, $M d$.)
}

(Submitted for publication October 8, 1962; accepted November 15, 1962)

The concept that idiopathic thrombocytopenic purpura (ITP) is an autoimmune disease led to vigorous efforts to demonstrate antibodies reacting with platelets in the blood of affected persons. After the first report by Evans and his associates (1) in 1951, Harrington and his co-workers (2) and others found platelet agglutinins in the serum of many patients with ITP, an observation considered to have immunologic implications. But in the course of these studies, serum of some patients without thrombocytopenia and of occasional healthy persons was noted to have plateletagglutinating activity (3-5). Jacklin, Furth, and Lozner (6) observed that the "false-positive" tests for platelet agglutinins encountered in normal persons could be eliminated by prior adsorption of serum with barium sulfate (100 mg per $\mathrm{ml}$ ), a procedure that lessened but did not eliminate the platelet-agglutinating activity of serum from patients with ITP. Methods for detecting agglutinins have varied, and results have been discordant. Corn and Upshaw (7) mechanically removed platelets from normal blood prior to coagulation and demonstrated that the serum caused platelet agglutination indistinguishable from that produced by serum of patients with ITP. Certain complex techniques including the antiglobulin consumption test have been reported to detect antibodies in some cases of ITP $(8,9)$, but standard immunologic procedures not dependent upon agglutination have yielded consistently negative

\footnotetext{
* This investigation was carried out under contract AT(30-1) 1208 between the Atomic Energy Commission and The Johns Hopkins University and was supported in part by research grant HE-01601 from the National Heart Institute, U. S. Public Health Service.

† Postdoctoral Fellow, U. S. Public Health Service.

$\ddagger$ Trainee, Hematology Training Grant, U. S. Public Health Service.
}

results $(7,10)$. Because of the uncertain status of platelet antibodies in ITP, the nature of the platelet-agglutinating activity of serum of patients with the disease was investigated.

\section{METHODS}

Blood was drawn into silicone-coated syringes or through plastic tubing. Containers were silicone-treated except where specified as plain glass. Anticoagulants employed were aqueous solutions of the disodium salt of EDTA, $2 \%$, or sodium citrate, $3.8 \% ; 1$ part of the solution was mixed with 9 parts of blood. Platelet-free and platelet-rich plasma was obtained as described elsewhere (11). For agglutination studies with serum, platelets were sedimented from 2 to $3 \mathrm{ml}$ of platelet-rich plasma, washed twice with $2 \mathrm{ml}$ of Tris-buffered saline containing EDTA (11), resuspended in serum, and incubated without agitation in plain glass tubes at $37^{\circ} \mathrm{C}$ for 30 minutes or longer, as specified in the experimental data. Platelet aggregation was evaluated with the use of a phase-contrast microscope. Degree of aggregation was arbitrarily graded from 0 to ++++ , the latter indicating the formation of large clumps with few single platelets remaining; these clumps were usually visible macroscopically when the platelet count exceeded 200,000 per $\mathrm{mm}^{3}$.

Trypsinized platelets were prepared by resuspending sedimented platelets in Tris-buffered saline containing salt-free trypsin $(50 \mu \mathrm{g}$ per $\mathrm{ml})$ and incubating at $37^{\circ} \mathrm{C}$ for 10 minutes; platelets were then sedimented and washed twice in Tris-buffered saline containing EDTA (11). The composition of Tris and phosphate buffers has been recorded $(11,12)$.

Residual prothrombin in serum was estimated by the method of Quick and Favre-Gilly (13) as modified by Dick, Jackson, and Conley (14). Platelets were counted by the method of Brecher and Cronkite (15). Retraction of plasma clots was measured and recorded as previously described (16). Clots were sectioned by the method of Gaintner, Jackson, and Conley (17).

Rabbit antihuman platelet serum was prepared by Corn and Upshaw (7). Human serum containing a platelet isoantibody was obtained from Dr. N. R. Shulman, National Institutes of Health, Bethesda, Md. Bovine throm- 
TABLE I

Platelet-agglutinating activity of serum of two adult female patients with ITP*

\begin{tabular}{cccc}
\hline & $\begin{array}{c}\text { Barium } \\
\text { sulfate } \\
\text { employed } \\
\text { to adsorb } \\
\text { serum }\end{array}$ & $\begin{array}{c}\text { Residual } \\
\text { prothrombin } \\
\text { time of } \\
\text { serum }\end{array}$ & $\begin{array}{c}\text { Aggregation } \\
\text { of normal } \\
\text { platelets }\end{array}$ \\
\hline E.P. & $m g / m l$ & sec & \\
(Platelet count, & 0 & 47 & ++++ \\
17,000 per $\mathrm{mm}^{3)}$ & 150 & $>120$ & ++++ \\
M.F. & 0 & 51 & ++++ \\
(Platelet count, & 50 & 72 & ++++ \\
68,000 per $\left.\mathrm{mm}^{8}\right)$ & 150 & $>120$ & 0 \\
Buffer control & & & 0
\end{tabular}

* ITP = idiopathic thrombocytopenic purpura. Neither patien had been treated by splenectomy or with steroid preparations. + Washed platelets from $2 \mathrm{ml}$ of normal platelet-rich plasma were suspended in $0.5 \mathrm{ml}$ of serum. Preparations were observed for agglutination after incubation at $37^{\circ} \mathrm{C}$ for 30 minutes.

bin was a commercial preparation supplied by Parke, Davis \& Co. Dr. K. L. Zierler (18) provided $d, l-\alpha$-tocopherol phosphate.

\section{RESULTS}

Aggregation of normal platelets by normal serum. A sample of $150 \mathrm{ml}$ of blood was drawn from a normal subject. Portions were transferred to plain glass and to silicone-coated tubes without anticoagulant, and to silicone-coated tubes containing a solution of EDTA. Platelet-rich plasma was obtained by centrifuging the EDTA blood. Platelets were sedimented and washed twice in Tris-buffered saline containing EDTA.

An uncoated glass tube containing $2 \mathrm{ml}$ of blood was vigorously shaken for 2 minutes to enhance prothrombin utilization. Clotting occurred in less than 5 minutes, and the tube was placed in a water bath at $37^{\circ} \mathrm{C}$ for 2 hours. Serum removed after centrifugation had a residual prothrombin time of 128 seconds, indicating that virtually none of the prothrombin remained. Washed platelets from $2 \mathrm{ml}$ of platelet-rich plasma suspended in $1 \mathrm{ml}$ of the serum remained unagglutinated after incubation at $37^{\circ} \mathrm{C}$ for 1 hour.

A plain glass tube containing $2 \mathrm{ml}$ of blood was placed without agitation in a water bath at $37^{\circ} \mathrm{C}$ for 2 hours. Serum removed after centrifugation had a residual prothrombin time of 40 seconds. Washed platelets suspended in this serum showed marked aggregation within 30 minutes. A portion of the serum was adsorbed with barium sulfate $(75 \mathrm{mg}$ per $\mathrm{ml})$. The adsorbed serum had a residual prothrombin time of 600 seconds and did not cause aggregation of washed platelets during incubation at $37^{\circ} \mathrm{C}$ for one hour.

Blood collected without anticoagulant in silicone-coated tubes was immediately centrifuged at $22,000 \mathrm{~g}$ for 10 minutes at $4^{\circ} \mathrm{C}$ to remove cells and platelets. The uncoagulated platelet-free plasma was transferred to plain glass tubes and allowed to clot during incubation at $37^{\circ} \mathrm{C}$ for 2 hours. Serum removed after compression of the clot had a residual prothrombin time of $16 \mathrm{sec}-$ onds. Washed platelets were markedly aggregated within 10 minutes when incubated in this serum. After adsorption with barium sulfate, 75 $\mathrm{mg}$ per $\mathrm{ml}$, the serum had a residual prothrombin time of 78 seconds and still caused pronounced aggregration of platelets. A portion of the serum adsorbed with barium sulfate, $150 \mathrm{mg}$ per $\mathrm{ml}$, had a residual prothrombin time exceeding $120 \mathrm{sec}-$ onds and did not produce aggregation of washed platelets during incubation for one hour. In similar experiments employing blood from two other normal subjects, serum prepared by clotting of platelet-free plasma had residual prothrombin times of 8 and 12 seconds, respectively. In these instances, adsorption of serum with barium sulfate, $150 \mathrm{mg}$ per $\mathrm{ml}$, did not inhibit platelet clumping, but adsorption with $300 \mathrm{mg}$ per $\mathrm{ml}$ did prevent aggregation.

Aggregation of normal platelets by serum of patients with ITP. Blood from two patients with ITP clotted in plain glass tubes during incubation at $37^{\circ} \mathrm{C}$ for 2 hours. Sterile serum removed after centrifugation was stored at $-20^{\circ} \mathrm{C}$ for less than 72 hours. Normal platelets suspended in each serum specimen were grossly clumped within 30 minutes, as viewed microscopically and macroscopically. Portions of each serum sample were adsorbed with barium sulfate and retested. Aggregation of platelets did not occur when serum was adsorbed with sufficient barium sulfate to remove virtually all of the residual prothrombin (Table I).

Serum from each of 12 patients with ITP was tested for its ability to agglutinate trypsinized platelets. Four of the cases were acute and eight were chronic. All of the patients had platelet counts less than 65,000 per $\mathrm{mm}^{3}$ at the time of the test. Splenectomy had previously been performed in six, and seven were being treated with predni- 
TABLE II

Platelet-agglutinating activity of serum of a patient apparently having a transferable antiplatelet factor

\begin{tabular}{|c|c|c|c|c|c|c|c|}
\hline \multirow[b]{3}{*}{ Source of serum } & & \multicolumn{6}{|c|}{ Source of platelets } \\
\hline & & \multicolumn{2}{|c|}{ Normal subject } & \multicolumn{2}{|c|}{ Patient } & \multicolumn{2}{|c|}{ Son of patient } \\
\hline & & Nontryp & $\overline{\text { Tryp }}$ & Nontryp & $\overline{\text { Tryp }}$ & Nontryp & $\overline{\text { Tryp }}$ \\
\hline \multirow{2}{*}{ Patient } & Unadsorbed & ++++ & 0 & $+t+$ & 0 & $+++t$ & 0 \\
\hline & $\begin{array}{l}\text { Adsorbed with } \\
\text { barium sulfate }\end{array}$ & 0 & 0 & 0 & 0 & 0 & 0 \\
\hline \multirow{2}{*}{ Normal subject } & Unadsorbed & $+t+t$ & 0 & ++++ & 0 & $++t+$ & + \\
\hline & $\begin{array}{l}\text { Adsorbed with } \\
\text { barium sulfate }\end{array}$ & 0 & 0 & 0 & 0 & 0 & 0 \\
\hline Buffer & & 0 & 0 & 0 & 0 & 0 & 0 \\
\hline
\end{tabular}

sone. Serum was obtained from blood that clotted during incubation in plain glass tubes at $37^{\circ} \mathrm{C}$ for 2 hours. Tests for platelet-agglutinating activity were performed immediately in six cases; in the others, sterile serum was stored at $-20^{\circ} \mathrm{C}$ for 2 to 18 days before testing. Treated platelets derived from $3 \mathrm{ml}$ of normal platelet-rich plasma were incubated at $37^{\circ} \mathrm{C}$ for 30 minutes in $0.5 \mathrm{ml}$ portions of serum. In 30 tests employing trypsinized platelets from seven normal donors, agglutination did not occur.

Studies of a patient with ITP apparently having a transferable antiplatelet factor. Tests were performed on one patient with chronic ITP whose child had had neonatal thrombocytopenic purpura.

L. B. (JHH 336066) was first examined at the Johns Hopkins Hospital in 1944 at age 30 because of thrombocytopenic purpura of at least 2 years' duration. No abnormalities were observed except for hemorrhagic manifestations, and the platelet count was 30,000 per $\mathrm{mm}^{3}$. A histologically normal spleen weighing $260 \mathrm{~g}$ was removed. Platelets rose to more than 200,000 per $\mathrm{mm}^{3}$ within one week and bleeding ceased. Five years later purpura recurred during the first month of the first pregnancy. Platelet count was 20,000 per $\mathrm{mm}^{3}$ and persisted at this low level. Stereoscopic X-ray films of the abdomen exposed after intravenous injection of Thorotrast showed no suggestion of an accessory spleen. Delivery was uncomplicated; there was only slight vaginal bleeding, and transfusions were not required.

The male infant weighed $2,900 \mathrm{~g}$ and appeared normal except for cutaneous purpura. Platelet count was 20. 000 per $\mathrm{mm}^{3}$ on the first day. Because of persistent bleeding and recurrent anemia due to blood loss, he was transfused repeatedly during the early weeks of life. At 2 months, bleeding had lessened and platelet count was 46,000 per $\mathrm{mm}^{3}$; at 6 months the count was 184,000 There has been no recurrence of bleeding or of throm- bocytopenia. The present study was performed when the child was 12 years old, displayed excellent health, and had a platelet count of 335,000 per $\mathrm{mm}^{3}$.

The patient continued to have severe thrombocytopenia and purpuric manifestations. At age 36 she had a second uncomplicated pregnancy. The child, born at another hospital, was transfused at one month of age, but there are no data pertaining to the platelets. The patient returned to the Johns Hopkins Hospital at age 48 for therapy with a steroid preparation. During administration of prednisone, $60 \mathrm{mg}$ per day, platelets rose from 15,000 to 85,000 per $\mathrm{mm}^{3}$ in one week and to 94,000 in 17 days.

Blood obtained from the patient prior to steroid therapy was allowed to clot in glass tubes at $37^{\circ} \mathrm{C}$ during an incubation period of 2 hours. Serum removed after centrifugation had a residual prothrombin time of 27 seconds. A portion of the serum was used immediately for studies with normal platelets; the remainder was stored under sterile conditions at $-20^{\circ} \mathrm{C}$ for 15 days for testing with the son's platelets and with the patient's own platelets after partial remission was induced with prednisone. Normal serum, prepared in the same manner, had a residual prothrombin time of 31 seconds. Portions of the serum specimens were adsorbed with barium sulfate, $150 \mathrm{mg}$ per $\mathrm{ml}$. Residual prothrombin time of the adsorbed serum of the patient exceeded 180 seconds; that of the normal serum was 124 seconds. Washed platelets, portions of which were treated with trypsin, were obtained from a normal person, from the patient's son, and from the patient. The sedimented platelets were resuspended in $0.5 \mathrm{ml}$ of serum and observed for aggregation after incubation at $37^{\circ} \mathrm{C}$ for 30 minutes. Results are 


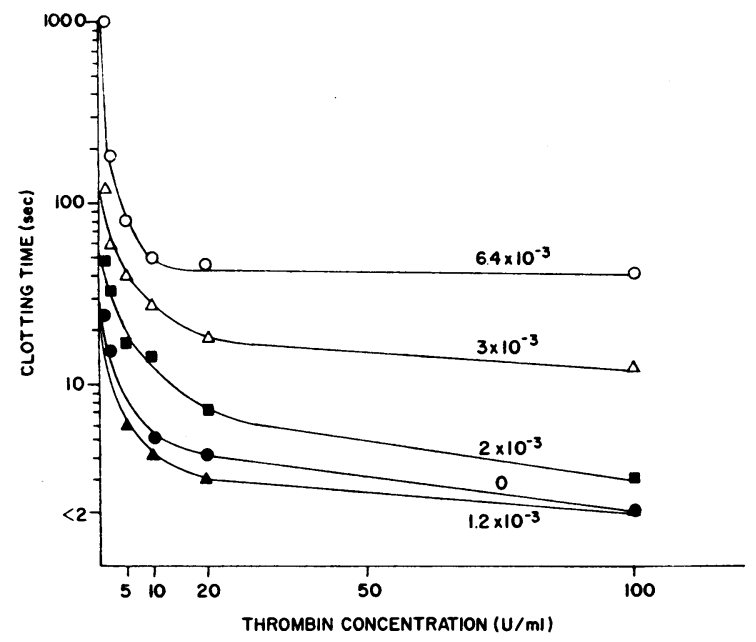

Fig. 1. EFFECt OF $\alpha$-TOCOPHEROL ON THE CLOTTING TIME OF CITRATED NORMAL PLATELET-RICH PLASMA AFTER ADDition of THROMBIN. To $0.3 \mathrm{ml}$ of plasma, $0.1 \mathrm{ml}$ of a solution of $\alpha$-tocopherol in $5 \%$ glucose was added, and the mixture was clotted with $0.1 \mathrm{ml}$ of thrombin solution at $37^{\circ} \mathrm{C}$. Final concentration of $\alpha$-tocopherol (M) is indicated on each line of the graph.

summarized in Table II. Aggregation of nontrypsinized platelets was produced within 30 minutes by normal and patient's serum when residual prothrombin was present, but trypsinized platelets were clumped by neither. Adsorption with barium sulfate abolished the platelet-aggregating activity of both normal and patient's serum. At the end of the 30 -minute incubation period, $0.4 \mathrm{ml}$ of normal EDTA platelet-free plasma was mixed with each suspension of platelets in serum. Clotting was induced by the addition of $0.2 \mathrm{ml} 0.05 \mathrm{M}$ calcium chloride and $0.1 \mathrm{ml}$ thrombin solution $(1,000 \mathrm{U}$ per $\mathrm{ml})$. After incubation for an additional hour, clots were observed for retraction. Retraction did not occur in the tubes in which the platelets had been aggregated, but was complete when platelet aggregation was prevented either by adsorption of serum with barium sulfate or by treatment of platelets with trypsin.

A portion of the patient's serum was submitted to Dr. N. R. Shulman, who tested it for antibody with a panel of platelets from six donors whose platelets have reacted with all isoantibodies detected by him up to this time. Serum was used at minimal dilution (half final concentration), and the platelet count was varied from 50,000 to 400 ,000 per $\mathrm{mm}^{3}$ in the presence of guinea pig complement. After incubation for 1 hour, residual complement was measured using a $50 \%$ hemolytic unit. No complement was fixed. Although this method has readily detected platelet isoantibodies, it has been incapable of demonstrating antibodies against platelets in the serum of other patients with ITP (10).

Inhibition of platelet aggregation by $\alpha$-tocopherol. The disodium salt of $d, l-\alpha$-tocopherol phosphate, a potent inhibitor of thrombin (18), was tested for its effects on platelet agglutination. $\mathrm{Ci}$ trated normal plasma containing various concentrations of $\alpha$-tocopherol was clotted with thrombin. The clot-retarding effect of $\alpha$-tocopherol was not significantly influenced by calcium concentration or platelet count, which ranged between 0 and 400,000 per $\mathrm{mm}^{3}$ in these experiments, but it was related to the concentration of thrombin and of $\alpha$-tocopherol (Figure 1). The rate and degree of platelet aggregation produced by thrombin was measured in platelet-rich plasma containing $\alpha$-tocopherol. One-tenth $\mathrm{ml}$ of a solution of $\alpha$-tocopherol in $5 \%$ glucose was mixed with $0.3 \mathrm{ml}$ of normal plasma containing 300,000 platelets per $\mathrm{mm}^{3}$. After incubation for 1 minute at $37^{\circ} \mathrm{C}$, $0.1 \mathrm{ml}$ of freshly prepared thrombin solution was added. The tubes were repeatedly tilted to produce gentle agitation, and the time required for macroscopically visible platelet aggregation and for coagulation was measured with a stopwatch. At all thrombin concentrations tested, platelet aggregation was inhibited during a period of obser-

TABLE III

Inhibitory effect of $\alpha$-tocopherol on platelet aggregation and coagulation induced by thrombin

\begin{tabular}{|c|c|c|c|c|c|c|c|c|c|c|c|c|}
\hline \multirow{4}{*}{$\frac{\text { Thrombin }}{U / m l}$} & \multicolumn{12}{|c|}{$\begin{array}{l}\text { Platelet aggregation time (A) and coagulation time } \\
\text { (C) after addition of thrombin (in seconds*) }\end{array}$} \\
\hline & \multicolumn{12}{|c|}{$\alpha$-tocopherol (M) } \\
\hline & \multicolumn{2}{|c|}{0} & \multicolumn{2}{|c|}{$1.2 \times 10^{-8}$} & \multicolumn{2}{|c|}{$2 \times 10^{-3}$} & \multicolumn{2}{|c|}{$3 \times 10^{-3}$} & \multicolumn{2}{|c|}{$6 \times 10^{-3}$} & \multicolumn{2}{|c|}{$1.2 \times 10^{-2}$} \\
\hline & A & C & $\mathrm{A}$ & C & A & $\mathrm{C}$ & $\mathrm{A}$ & C & A & C & A & C \\
\hline 1 & & 24 & & 29 & 22 & 47 & 32 & 120 & 50 & 1080 & $\infty$ & $\infty$ \\
\hline 2 & & 15 & & 15 & 23 & 32 & 20 & 60 & 30 & 180 & $\infty$ & $\infty$ \\
\hline 5 & & 6 & & 6 & & 16 & 20 & 40 & 17 & 80 & $\infty$ & $\infty$ \\
\hline 10 & & 5 & & 4 & & 14 & 15 & 27 & 20 & 50 & $\infty$ & $\infty$ \\
\hline 20 & & 4 & & 3 & & 7 & 12 & 18 & 17 & 45 & $\infty$ & $\infty$ \\
\hline 100 & & 2 & & 2 & & 3 & 7 & 12 & 19 & 40 & $\infty$ & $\infty$ \\
\hline 200 & & 2 & & 2 & & 3 & & 7 & 18 & 30 & $\infty$ & $\infty$ \\
\hline
\end{tabular}

* Where platelet aggregation time is not recorded, aggregation was not observed prior to clotting. Final concentrations of $\alpha$-tocophero and thrombin are recorded. With concentrations of $\alpha$-tocopherol of $6 \times 10^{-3}$, fibrin strands appeared, but solid clots were never formed. At a concentration of $1.2 \times 10^{-2}$, no fibrin was seen microscopically, but a flocculant precipitate appeared after 120 to 1,500 seconds. The symbol $\infty$ indicates the reaction did not occur during a period of ob-
servation of at least 4 hours. 


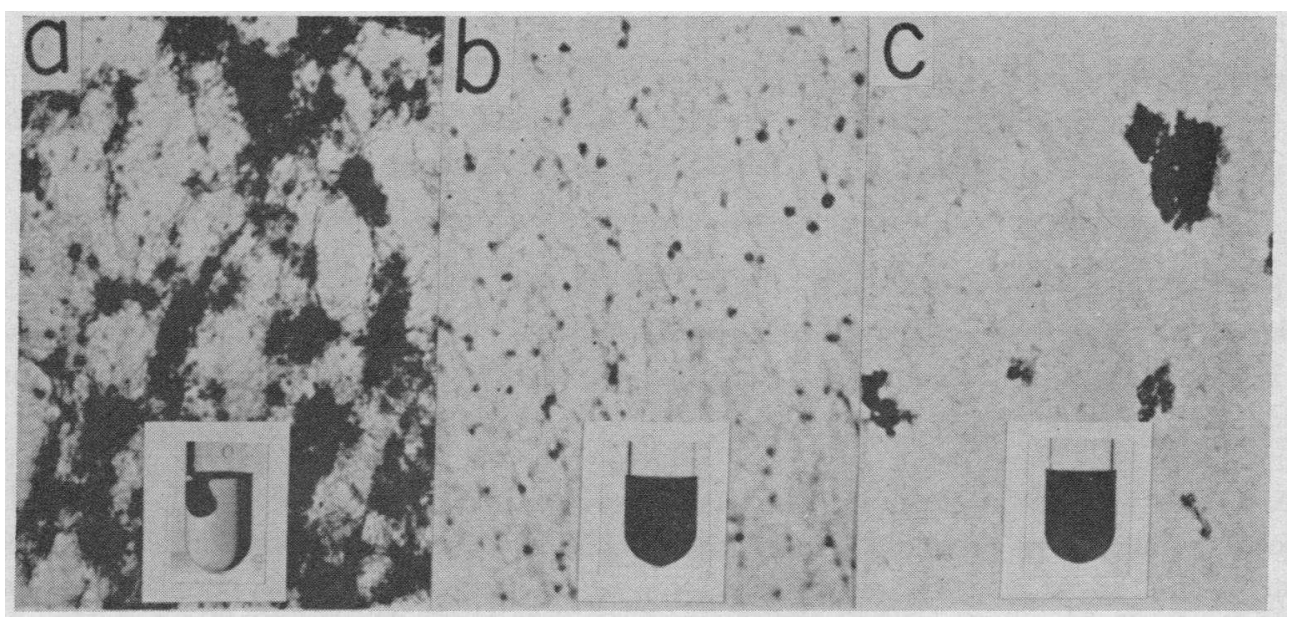

Fig. 2. Sections of plasma clots containing platelets that pReviously had been exPOSED TO (A) SERUM FROM A PATIENT WITH ITP, (B) HUMAN SERUM CONTAINING AN ISOANTIBODY REACTING WITH PLATELETS, AND (c) RABBit ANTIHUMAN PLATELET SERUM $(\times 750)$.

The degree of retraction of the clots at the time of fixation is shown in the inserts.

vation of at least 4 hours by an amount of $\alpha$-tocopherol sufficient to prevent coagulation (Table III).

The effect of $\alpha$-tocopherol on the platelet-agglutinating activity of serum from two patients with ITP was investigated. Platelet aggregation was abolished by a concentration of $\alpha$-tocopherol that had been demonstrated to prevent aggregation of platelets by thrombin (Table IV). In contrast, the platelet-agglutinating effect of rabbit antihuman platelet serum was not measurably affected by this concentration of $\alpha$-tocopherol.

Effect of serum containing EDT $A$ on the clotretracting activity of platelets. Serum to which EDTA was added to prevent thrombin formation was tested for a possible deleterious effect upon platelets, as measured by their ability subsequently to produce clot retraction. Platelets from $3 \mathrm{ml}$ of platelet-rich plasma were resuspended in $2 \mathrm{ml}$ of phosphate buffer containing EDTA, $2 \mathrm{mg}$ per $\mathrm{ml}$. Two-tenths $\mathrm{ml}$ portions of the platelet suspension were mixed with $0.8 \mathrm{ml}$ portions of serum to which EDTA, $2 \mathrm{mg}$ per $\mathrm{ml}$, had been added. Final concentration of platelets was approximately 250,000 per $\mathrm{mm}^{3}$. After incubation at $37^{\circ} \mathrm{C}$ for 30 minutes, platelets were sedimented and resuspended in $0.9 \mathrm{ml}$ of citrated normal platelet-free plasma. Coagulation was induced with 0.1 $\mathrm{ml}$ thrombin solution ( $50 \mathrm{U}$ per $\mathrm{ml}$ ), and the clot was examined for retraction after 1 hour at $37^{\circ} \mathrm{C}$. Serum derived from blood that had clotted in plain glass tubes during an incubation period of 2 hours at $37^{\circ} \mathrm{C}$ was obtained from three normal subjects, seven patients with ITP, a patient with a platelet isoantibody, normal rabbits, and rabbits immunized against human platelets. EDTA serum from normal persons, from patients with ITP, and from normal rabbits did not impair the clot-retracting activity of platelets. Serum containing the isoantibody completely inhibited retraction activity, although it did not agglutinate

TABLE IV

Effect of $\alpha$-tocopherol on the platelet-agglutinating activity of serum from patients with ITP and of rabbit antihuman platelet serum*

\begin{tabular}{cccc}
\hline \hline & \multicolumn{2}{c}{$\begin{array}{c}\text { Time required for macro- } \\
\text { scopically visible platelet } \\
\text { aggregation }\end{array}$} \\
\cline { 2 - 4 } $\begin{array}{c}\alpha \text {-Tocopherol } \\
\text { (final con- } \\
\text { centration) }\end{array}$ & $\begin{array}{c}\text { Patient } \\
\text { M.F. }\end{array}$ & $\begin{array}{c}\text { Pabbit } \\
\text { E.P. }\end{array}$ & $\begin{array}{c}\text { Ratihuman } \\
\text { platelet } \\
\text { serum }\end{array}$ \\
\hline$M$ & min & min & min \\
0 & 4 & 4 & 12 \\
$1.2 \times 10^{-3}$ & 5 & 5 & 12 \\
$2 \times 10^{-3}$ & 5 & 5 & 12 \\
$6 \times 10^{-3}$ & 9 & 13 & 12 \\
$1.2 \times 10^{-2}$ & $\infty$ & $\infty$ & 12 \\
\hline
\end{tabular}

* Washed normal platelets were suspended in a mixture of $0.4 \mathrm{ml}$ of serum and $0.1 \mathrm{ml}$ of solution of $\alpha$-tocopherol in $5 \%$ glucose. Platelet concentration was approximately 300,000 per $\mathrm{mm}^{3}$. The test was performed at $37^{\circ} \mathrm{C}$. Platelets remained unaggregated during a period of observation of at least four hours when suspended in buffer, glucose solution, or serum from which prothrombin had been removed with barium sulfate. 
the platelets. Rabbit antihuman platelet serum grossly agglutinated platelets and abolished their ability to cause retraction of clots (Figure 2).

\section{DISCUSSION}

Platelets tend to aggregate during the coagulation of blood, an observation recorded by Hayem (19) in 1878. Wright and Minot (20) demonstrated that washed platelets are clumped by fresh serum, and Fonio (21) and many others recognized the platelet-aggregating activity of thrombin. Recent studies have shown that the effect of normal serum on platelets is attributable to thrombin, which displays this activity only in the presence of divalent cations $(11,22,23)$. The action of thrombin appears to be mediated by fibrinogen bound to the surface of platelets (11). Fibrinogen cannot be eluted from platelets by repeated washing (24), but is removed during their exposure to trypsin (11). Thrombin formed during coagulation is rapidly inactivated by antithrombin (25), but variable amounts of prothrombin may remain in the serum. When thrombocytopenic blood coagulates, relatively large amounts of prothrombin persist $(26,27)$. Significant amounts may remain in the serum of normal blood, depending upon the manner in which the blood is handled (14). If serum containing prothrombin is mixed with thromboplastic materials or with platelets, additional thrombin is generated (28).

In the experiments that have been described, platelets were aggregated by normal serum when residual prothrombin was present; when virtually no prothrombin remained, serum did not agglutinate platelets. Aggregation was prevented by removal of prothrombin from serum by adsorption; the quantity of barium sulfate required was related to the amount of residual prothrombin. Aggregation was not produced by prothrombinrich serum after fibrinogen had been removed from platelets by trypsin. Clumping of platelets by thrombin previously has been shown to be inhibited by heparin. A concentration of heparin adequate to prevent coagulation may be insufficient to inhibit platelet aggregation, an observation suggesting that under some conditions platelet clumping is a more sensitive indicator of thrombin activity than the coagulation of fibrino- gen in plasma $(11,29)$. Another thrombin-inhibitory agent, $\alpha$-tocopherol, prevented aggregation of platelets by thrombin when present in a concentration adequate to suppress clotting. EDTA in relatively high concentration also prevents clumping of platelets by serum $(4,6)$.

Antibodies that react with platelets are wellknown. Heterologous antibodies may be produced by injection of platelets into animals (30). Thrombocytopenia induced by certain drugs is attributable to an antibody reacting with an antigen complex consisting of the drug and platelets (31). Isoantibodies reacting with specific, genetically determined platelet antigens have been encountered after transfusion or pregnancy (10, $32,33)$. In each of these instances the serum component reacting with platelets has the properties of a classic antibody, and complement is fixed during the reaction. Platelet isoantibodies as well as heterologous antihuman platelet serum react with trypsinized platelets $(10,11)$. In the present study, two types of complement-fixing antibodies were tested. Rabbit antihuman platelet serum strongly agglutinated human platelets and prevented clot-retraction. Platelet-agglutinating activity of this serum did not require the presence of divalent cation, was not inhibited by $\alpha$-tocopherol in concentrations that blocked the action of thrombin, and was undiminished with platelets that had been treated with trypsin. The platelet isoantibody used in these experiments inhibited clot retraction, but had no demonstrable platelet-agglutinating activity under the conditions employed.

Serum from patients with ITP caused aggregation of washed platelets, an effect that was abolished by prior adsorption of the serum with barium sulfate. Relatively large amounts of barium sulfate were necessary to eliminate the platelet-agglutinating activity of serum derived from thrombocytopenic blood. Platelets that had been exposed to trypsin and were not aggregated by thrombin also were not agglutinated by fresh ITP serum. Furthermore, $\alpha$-tocopherol inhibited agglutination of platelets by serum of patients with ITP. These observations suggest that the platelet agglutinin demonstrable in the serum of many patients with ITP is thrombin, derived from residual prothrombin during admixture of serum and platelets. The amount of thrombin formed during the test procedure is determined in part 
by the concentration of residual prothrombin, a variable related to the platelet count of the blood and to the technique of handling the specimen. In addition, the type and concentration of anticoagulant employed are critical determinants.

Most of the recognized platelet antibodies have platelet-agglutinating properties. But aggregates of platelets produced by antibodies ordinarily cannot be distinguished from those formed by thrombin. Accordingly, special precautions and confirmatory tests are required to eliminate thrombin as a factor before concluding that a platelet agglutinin is an antibody. Thrombin may cause aggregation of platelets in concentrations too low to be detected by other means.

There is a reasonable basis for the concept that ITP is an autoimmune disease. Infants born of mothers with the disorder may have neonatal thrombocytopenia (34). Transfusion of plasma from patients with ITP to normal recipients has produced transient thrombocytopenia (35). Normal platelets often have a short survival time when administered to patients with $\operatorname{ITP}(36,37)$. Acquired hemolytic anemia with demonstrable autoantibodies against erythrocytes occasionally has been encountered in patients who also had thrombocytopenia (38). Adrenocortical hormones that block certain antibody responses are effective in the treatment of some patients with ITP and are reported to inhibit formation of antibodies against human platelets in rabbits (39). Splenectomy, a procedure that may be beneficial in ITP, renders rats less susceptible to the thrombocytopenic effects of heterologous antiplatelet serum (2).

The observations described in this report by no means exclude the possibility that ITP is an autoimmune disorder. They do support the conclusion of Corn and Upshaw (7) that antibodies reacting with platelets have not been convincingly demonstrated in the blood of patients with the disease.

\section{SUMMARY}

Normal platelets were aggregated by serum of patients with idiopathic thrombocytopenic purpura (ITP). Platelet-agglutinating activity was abolished by adsorption of the serum with a quantity of barium sulfate sufficient to remove residual prothrombin. The amount of barium sulfate required was related to the concentration of prothrombin in serum. A thrombin-inhibitory agent, $\alpha$-tocopherol, also prevented platelet aggregation. Trypsinized platelets that were not aggregated by thrombin also were not agglutinated by fresh serum of patients with ITP. These observations indicate that the platelet agglutinin in the serum of patients with ITP is thrombin, derived from prothrombin remaining after coagulation of thrombocytopenic blood.

\section{ACKNOWLEDGMENT}

Miss Judy King provided valuable technical assistance.

\section{REFERENCES}

1. Evans, R. S., K. Takahasi, R. T. Duane, R. Payne, and $\mathrm{C}-\mathrm{K}$. Liu. Primary thrombocytopenic purpura and acquired hemolytic anemia. Evidence for a common etiology. Arch. intern. Med. 1951, 87, 48.

2. Harrington, W. J., C. C. Sprague, V. Minnich, C. V. Moore, R. C. Aulvin, and R. Dubach. Immunologic mechanisms in idiopathic and neonatal thrombocytopenic purpura. Ann. intern. Med. 1953, 38, 433.

3. Harrington, W. J., V. Minnich, and G. Arimura. The antoimmune thrombocytopenias in Progress in Hematology, L. M. Tocantins, Ed. New York, Grune \& Stratton, 1956, vol. 1, p. 166.

4. Lundevall, J. Serological Studies of Human Blood Platelets. Oslo, Oslo University Press, 1958.

5. Dausset, J., M. Colin, and J. Colombani. Immune platelet isoantibodies. Vox Sang. (Basel) 1960, $5,4$.

6. Jacklin, H. N., F. W. Furth, and E. L. Lozner. Studies on the causes of false-positive results in the laboratory detection of platelet agglutinins in thrombocytopenic purpura. Amer. J. clin. Path. 1961, 36, 95.

7. Corn, M., and J. D. Upshaw, Jr. Evaluation of platelet antibodies in idiopathic thrombocytopenic purpura. Arch. intern Med. 1962, 109, 157.

8. Moulinier, J. Le test de consommation d'antiglobuline appliqué à la recherche des anticorps antithrombocytes. Sang 1955, 26, 811.

9. Steffen, C. Results obtained with the antiglobulin consumption test and investigations of autoantibody eluates in immunohematology. J. Lab. clin. Med. 1960, 55, 9.

10. Shulman, N. R., R. H. Aster, A. Leitner, and M. C. Hiller. Immunoreactions involving platelets. V. Post-transfusion purpura due to a complement- 
fixing antibody against a genetically controlled platelet antigen. A proposed mechanism for thrombocytopenia and its relevance in "autoimmunity." J. clin. Invest. 1961, 40, 1597.

11. Schmid, H. J., D. P. Jackson, and C. L. Conley. Mechanism of action of thrombin on platelets. J. clin. Invest. 1962, 41, 543.

12. Gaintner, J. R., D. P. Jackson, and E. W. Maynert. The action of thrombin on platelet 5-hydroxytryptamine. Bull. Johns Hopk. Hosp. 1962, 111, 185.

13. Quick, A. J., and J. E. Favre-Gilly. The prothrombin consumption test: its clinical and theoretic implications. Blood 1949, 4, 1281.

14. Dick, F. W., D. P. Jackson, and C. L. Conley. Surface as a quantitative factor in prothrombin utilization. J. clin. Invest. 1954, 33, 1423.

15. Brecher, G., and E. P. Cronkite. Morphology and enumeration of human blood platelets. J. appl. Physiol. 1950, 3, 365.

16. Hartmann, R. C., and C. L. Conley. Clot retraction as a measure of platelet function. I. Effects of certain experimental conditions on platelets in vitro. Bull. Johns Hopk. Hosp. 1953, 93, 355.

17. Gaintner, J. R., D. P. Jackson, and C. L. Conley. Morphologic studies of clot retraction. Bull. Johns Hopk. Hosp. 1962, 111, 266.

18. Zierler, K. L., D. Grob, and J. L. Lilienthal, Jr. On the antithrombic and antiproteolytic activity of alpha tocopheryl phosphate. Amer. J. Physiol. 1948, 153, 127.

19. Hayem, G. Sur la formation de la fibrine du sang étudiée au microscope. C. R. Acad. Sci. (Paris) 1878, 86, 58.

20. Wright, H. J., and G. R. Minot. The viscous metamorphosis of the blood platelets. J. exp. Med. 1917, 26, 395.

21. Fonio, A. Untersuchungen der Thrombozyten im Dunkelfeld-nativpräparat. Vorläufige Mitteilung. Schweiz med. Wschr. 1939, 69, 952.

22. Stefanini, M. Autocatalytic formation of thrombin in blood coagulation. Acta. med. scand. 1951, 140, 290.

23. Shermer, R. W., R. G. Mason, R. H. Wagner, and K. M. Brinkhous. Studies on thrombin-induced platelet agglutination. J. exp. Med. 1961, 114, 905.

24. Seligmann, M., B. Goudemand, A. Janin, J. Bernard, and P. Grabar. Etudes immunochimiques sur la présence de fibrinogène dans des extraits de plaquettes humaines lavées et dans certains extraits leucocytaires. Rev. Hémat. 1957, 12, 302.

25. Gasser, H. S. The significance of prothrombin and of free and combined thrombin in blood serum. Amer. J. Physiol. 1917, 42, 378.

26. Conley, C. L., R. C. Hartmann, and W. I. Morse II. The clotting behavior of human "platelet-free" plasma: evidence for the existence of a "plasma thromboplastin." J. clin. Invest. 1949, 28, 340.

27. Quick, A. J., J. N. Shanberge, and M. Stefanini. The role of platelets in the coagulation of the blood. Amer. J. med. Sci. 1949, 217, 198.

28. Stefanini, M., and J. H. Silverberg. Studies on platelets. I. The relationship of platelet agglutination to the mechanism of blood coagulation. Amer. J. clin. Path. 1951, 21, 1030.

29. Mason, R. G., E. J. Hocutt, R. H. Wagner, and K. M. Brinkhous. Evolution and decay of plateletagglutinating activity in normal and pathologic human plasmas. J. Lab. clin. Med. 1962, 59, 645.

30. Cole, R. I. Note on the production of an agglutinating serum for blood platelets. Bull. Johns Hopk. Hosp. 1907, 18, 261.

31. Ackroyd, J. F. The role of complement in sedormid purpura. Clin. Sci. 1951, 10, 185.

32. Van Loghem, J. J., Jr., H. Dorfmeijer, M. van der Hart, and F. Schreuder. Serological and genetical studies on a platelet antigen $(\mathrm{Zw})$. Vox Sang. (Basel) 1959, 4, 161.

33. Shulman, N. R., R. H. Aster, H. A. Pearson, and M. C. Hiller. Immunoreactions involving platelets. VI. Reactions of maternal isoantibodies responsible for neonatal purpura. Differentiation of a second platelet antigen system. J. clin. Invest. 1962, 41, 1059.

34. Epstein, R. D., E. L. Lozner, T. S. Cobbey, and C. S. Davidson. Congenital thrombocytopenic purpura. Purpura hemorrhagica in pregnancy and in the newborn. Amer. J. Med. 1950, 9, 44.

35. Harrington, W. J., V. Minnich, J. W. Hollingsworth, and C. V. Moore. Demonstration of a thrombocytopenic factor in the blood of patients with thrombocytopenic purpura. J. Lab. clin. Med. 1951, 38, 1.

36. Stefanini, M., J. B. Chatterjea, W. Dameshek, L. Zannos, and E. Perez Santiago. Studies on platelets. II. The effect of transfusion of platelet-rich polycythemic blood on the platelets and hemostatic function in "idiopathic" and "secondary" thrombocytopenic purpura. Blood 1952, 7, 53.

37. Hirsch, E. O., and F. H. Gardner. The transfusion of human blood platelets. J. Lab. clin. Med. 1952, 39, 556.

38. Evans, R. S., and R. T. Duane. Acquired hemolytic anemia. I. The relation of erythrocyte antibody production to activity of the disease. II. The significance of thrombocytopenia and leukopenia. Blood 1949, 4, 1196.

39. Suhrland, L. G., E. R. Arquilla, and A. S. Weisberger. The effect of prednisolone on circulating antibody formation in animals immunized with human platelet antigen. J. Lab. clin. Med. 1958, $51,724$. 